\title{
Valentina Dinica
}

\section{Protected

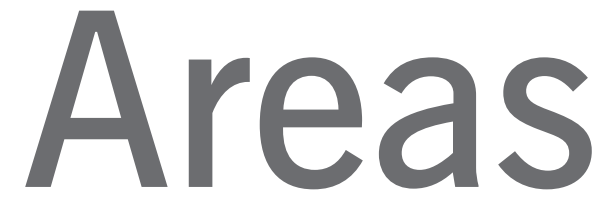 how will they contribute to}

\section{third millennium challenges?}

Biodiversity is valued for its intrinsic worth and for its role in generating ecosystem services, such as soil fertility, clean air, renewable bio-resources, and water quality and availability. While biodiversity outcomes are generally pursued by nations for land in various types of ownership, this article focuses on protected areas on publicly owned lands. ${ }^{1}$ Currently, the internationally agreed protected area classification used by the United Nation's Convention on Biological Diversity differentiates them in terms of nature conservation objectives and 'compatible' human uses. This suggests that protected areas can be arranged along a spectrum of protection stringency, from reserves and wilderness areas at one end, to so-called 'sustainable use lands' at the other (Dudley, 2008, p.24). Some apply even more extreme interpretations, viewing protected areas and approaches to their management in terms of dichotomies: segregated/'fortress conservation'

Valentina Dinica is Senior Lecturer in Public Policy at the School of Government. She teaches on environmental policy and policy analysis. Her research focuses on sustainability issues, particularly sustainable nature-based tourism, protected area governance, renewable energy, climate change and water management versus integrated conservation (Mose and Weixlbaumer, 2007; Rodary and Milian, 2011).

Drawing on an overview of protected area evolution and key contemporary challenges faced, this article argues that the idea of compatibility with specific human uses gives a false sense of security. Human activities occur in protected areas of most types. The expected exponential increase in population growth compounds the challenges surrounding their use. The complex biogeochemical processes generated by harmful human interventions reverberate beyond local level. They exert an impact on regional biosphere processes, contributing to negative global environmental changes. Over various timeframes, biodiversity and ecosystem health in protected areas will also be affected (Rockstrom et al., 2009a). Acknowledging these multi-scale interactions, and taking a long-term view, compels us to rethink the regulatory conditions applicable to human access to protected areas and the governance objectives underpinning them.

This article proposes the use of the recently developed Planetary Boundary 
Box 1: Values of protected natural areas

\begin{tabular}{|c|c|c|c|c|}
\hline \multicolumn{3}{|c|}{ Use values } & \multicolumn{2}{|c|}{ Non-use values } \\
\hline Direct use & Indirect use & Option value & Bequest values & Existence values \\
\hline Recreation and tourism & Ecosystem services & Future information & $\begin{array}{l}\text { Use and non-use values } \\
\text { for legacy }\end{array}$ & Biodiversity \\
\hline Sustainable harvesting & Climate stabilisation & & Future uses & Ritual or spiritual values \\
\hline Wildlife harvesting & $\begin{array}{l}\text { Natural services } \\
\text { Watershed protection }\end{array}$ & & & \\
\hline Gene harvesting & Flood control & & & Culture, heritage \\
\hline Fuel-wood & Groundwater recharge & & & Community values \\
\hline Grazing & Carbon sequestration & & & Landscape values \\
\hline Research & Habitat & & & \\
\hline Agriculture & Nutrient retention & & & \\
\hline Education & Natural disaster preve & & & \\
\hline
\end{tabular}

Source: IUCN, 1998, p.13

framework (Steffen et al., 2015) as a reference point in the effort to select a more comprehensive set of objectives to guide protected area governance. This revised set draws on global environmental sustainability considerations, an approach that does not undermine the prioritisation of various aspects and features of nature at protected area level. The article also suggests a broad research agenda, to tackle the implications of revising objectives for how protected areas are regulated and integrated into the wider policy and institutional settings. Brief reflections on the New Zealand situation flesh out theoretical discussions.

\section{A brief history of protected areas: values and management objectives}

Governments and other landowners have employed the concept of protected areas for centuries. Protected areas were first established as reserves in the 16th century, to prevent the extinction of individual iconic species, such as the bison and chamois, in some European countries (Dixon and Sherman, 1990, p.9). National parks emerged in late 19th century: Yellowstone was the first national park established, in the United States, in 1872.

New Zealand established its first national park in 1887, when Ngāti Tūwharetoa chief Horonuku Te Heuheu gifted the volcanoes Ruapehu, Ngāuruhoe and Tongariro to the Crown. The Tongariro National Park was formed, to be managed by the government for the enjoyment of all New Zealanders. A key motivation was to protect the volcanoes, which are sacred to Māori, from acquisition by British settlers (Department of Conservation and Tongariro Natural History Society, 1998). Many national parks were created with an emphasis on recreational needs, through the enjoyment of quality landscapes and/or hunting, and minimising other uses. The initial management approach is referred to in the literature as 'segregated use' or 'land sparing' (Ellis, 2013). Western countries (especially Anglo-Saxon) later exported this model to colonised countries in the developing world. This often involved removing indigenous populations from their lands (Adams and Mulligan, 2003).

From the middle of the 20th century there has been a diversification of the values underpinning nature protection, to include, for example, their intrinsic worth, education and research, and future values. Societies have also started to acknowledge that many benefits of protected areas can be harnessed through economic instruments, like user-pay fees and payment for ecosystem services. The International Union for Conservation of Nature (IUCN) proposed a classification of protected area values that can be monetised, as shown in Box 1.

Given that some areas are more ecologically valuable and/or vulnerable than others, there have always been differences in how nature values are prioritised across locations. This has resulted in countless protected area types. For example, New Zealand distinguishes among 60 types of protected areas, the most important of which are: national parks; conservation parks; nature reserves; scientific reserves; scenic reserves; historic reserves; land, recreation (and other) reserves; specially protected areas; and protected marine areas (Molloy, 2016). To enable international agreements and improve communication, the IUCN elaborated a protected area typology in the 1960s. The decision was taken at the first world congress on protected areas in 1962 (Rodary and Milian, 2013, p.13). The classification is not compulsory for national governments, but it has been revised several times to incorporate criticism. Currently it defines six categories, as adopted at the 1992 Caracas World Congress on National Parks and Protected Areas (Dudley, 2008). Category I is split in two, as shown in Box 2. The United Nation's Convention on Biological Diversity was opened for signature by national governments in 1992 and uses this classification.

An important observation is that protected area definitions are narrowly focused on nature. According to the IUCN, a protected area is a space 'recognised, dedicated and managed ... to achieve the long-term conservation of nature with associated ecosystem services and cultural values' (Dudley, 2008, p.8). Assessing the prospects for successfully meeting the Convention on Biological Diversity targets for 2020 (see next section), a group of IUCN affiliated authors and collaborators write:

For our purposes, nature, defined as 'biodiversity', comes first. The protected area definition used by CBD, defined in Article 2 of the 
Box 2: Types of protected area under the IUCN/Convention on Biological Diversity classification

\section{Category I}

Ia: Strict Nature Reserves: are strictly protected areas set aside to protect biodiversity and also possibly geological/geomorphical features, where human visitation, use and impacts are strictly controlled and limited to ensure protection of the conservation values.

Ib: Wilderness Areas: usually large unmodified or slightly modified areas, retaining their natural character and influence without permanent or significant human habitation, which are protected and managed so as to preserve their natural condition.

Category II

National Parks: large natural or nearly natural areas set aside to protect large-scale ecological processes, along with the complement of species and ecosystems characteristic of the area, which also provide a foundation for environmentally and culturally compatible, spiritual, scientific, educational, recreational, and visitor opportunities.

\section{Category III}

Natural Monuments: set aside to protect a specific natural monument, which can be a landform, sea mount, submarine cavern, geological feature such as a cave or even a living feature such as an ancient grove. They are generally quite small protected areas and often have high visitor value.

\section{Category IV}

Habitat/Species Management Areas: to protect particular species or habitats and management reflects this priority. Many Category IV protected areas will need regular, active interventions to address the requirements of particular species or to maintain habitats, but this is not a requirement of the category

Category V

Protected Landscape/Seascapes: where the interaction of people and nature over time has produced an area of distinct character with significant, ecological, biological, cultural and scenic value; and where safeguarding the integrity of this interaction is vital to protecting and sustaining the area and its associated nature conservation and other values.

\section{Category VI}

Managed Resource Protected Area: protected areas conserve ecosystems and habitats together with associated cultural values and traditional natural resource management systems. They are generally large, with most of the area in a natural condition, where a proportion is under sustainable natural resource management and where low-level non-industrial use of natural resources compatible with nature conservation is seen as one of the main aims of the area.

Source: Dudley, 2008, pp.12-24

Convention, is similar in intent and scope and we treat both definitions as being essentially equivalent: 'The term protected area is a geographically defined area, which is designated or regulated and managed to achieve specific conservation objectives'.

(Woodley et al., 2012, p.31)

Such definitions differ from those adopted by many countries. The implication is that protected areas identified by the same terms, such as reserve or national park, can be classified in any IUCN category. For example, 15 of the United Kingdom's national parks are classified as category $\mathrm{V}$, while the rest are listed as in 'not reported' management status. In contrast, all New Zealand's national parks are acknowledged as category II. In the United States, 132 national parks are recognised as category II, but others are not (UNEP-WCMC, 2014). In this article, the term protected area is used broadly, to also include national efforts not reflected in the IUCN/Convention on Biological Diversity classification shown in Box 2.

\section{The expansion of protected areas and challenges ahead}

Globally, the number and extent of protected areas remained low until the end of the Second World War, and they were predominantly found in developed countries. Developing countries have been expanding their protected area network quite rapidly since the mid-1970s. The total area protected under the Convention on Biological Diversity constituted $15.4 \%$ of terrestrial and inland water areas in 2014, but only $8.4 \%$ of the global ocean (United Nations Environmental Programme, 2014, p.ii). Only $65 \%$ of these areas used the IUCN classification (ibid., p.4). Target 11 of the Aichi Strategic Plan adopted under the convention in 2010 aims to lift the minimum percentage of terrestrial protected areas globally to $17 \%$ by 2020 , and of marine and coastal areas to $10 \%$. This includes those with 'not reported' status, because, although their primary objective may not be 'to achieve the longterm conservation of nature', this is often a helpful secondary objective (ibid.).

Table 1 shows the shares and types of protected areas for some key regions, including the ocean/marine-based ones. With the exception of Oceania, categories I and II have the lowest shares. Strikingly, only around $1 \%$ of Europe's national parks are recognised as category II national parks in the IUCN classification. This is often because human habitation pre-dates protected area establishment and the types and levels of human use are considered insufficient to warrant such classification (Mose and Weixlbaumer, 2007). Categories III and IV were very popular until a few decades ago. Category III sites are usually small-scale (less than $10 \mathrm{~km}^{2}$ ), while category IV sites focus narrowly on protection of (often individual) species and habitats (Rodary and Milian, 2011, pp.20-1). The highest shares are represented by protected areas with 'not reported' management forms, dominating in Africa. Since the 1990s, categories V and VI have been growing most strongly (Rodary and Milian, 2011, p.21). 
Conservationists and biologists call for a significant expansion of all protected area types, striving for an average of 50\% of the planet (Noss et al., 2012). However, population growth will limit that, and may influence the social acceptability of some protected areas, especially categories I and II. On 6 January 2016 the global population passed 7,392,818,500. ${ }^{2}$ The United Nations estimations are that by 2100 there will be almost 11 billion human beings on Earth. Table 2 indicates the expected growth across regions.

Population growth is expected to have an impact on biodiversity and ecosystem health both directly and indirectly, through increased demand for housing, food, energy, and other goods and services (Mora and Sale, 2011). Many developed countries, which do not suffer yet from population pressures, are above the Aichi target of 17\% already: for example, protected areas cover $28 \%$ of the United States, one third of New Zealand, and around half of Tasmania (UNEP-WCMC, 2014). The problem lies with the prospects for protected area increase in Africa, Asia and South America. For example, less than 12\% of land is uninhabited in Africa. According to Balmford et al. (2001), the lands with high ecological value have already been occupied, and many of these areas exhibit strongly positive relationships between biodiversity and people. This makes protected area network expansion, even preservation, difficult. Ehrlich and Pringle give as an example Venezuelan president Hugo Chávez's plans to relocate 100,000 people in El Álvila National Park to address overcrowding in Caracas (Ehrlich and Pringle, 2008, p.11580). If protected areas are to be defendable in the context of population growth, decision-makers need to rethink how they govern human-nature interactions in such spaces, starting with a reconsideration of the objectives to be pursued.

Table 1: Protected areas by region

Shares in

\begin{tabular}{|c|c|c|c|}
\hline $\begin{array}{l}\text { Continent/ } \\
\text { Region }\end{array}$ & $\begin{array}{l}\text { Terrestrial } \\
\text { areas (\%) }\end{array}$ & $\begin{array}{l}\text { Marine } \\
\text { areas } \\
(\%)\end{array}$ & $\begin{array}{l}\text { Protected area types, listed in decreasing order of their } \\
\text { shares }\end{array}$ \\
\hline Africa & 14.7 & 2.4 & NR: 86\%; \\
\hline Asia & 12.4 & 4.5 & III \& IV: 45\%; V \& VI: 32\%; I \& II: $18 \%$ \\
\hline Europe & 13.6 & 3.9 & NR: 43\%; III - IV: $\sim 39 \%$; V - VI: $\sim 11 \%$; I: 6\%; II: 1\% \\
\hline Middle East & 15.2 & 1 & NR: $\sim 45-50 \%$; III - IV: 33\%; V - VI: $12 \%$; I \& II: $6 \%$ \\
\hline $\begin{array}{l}\text { North } \\
\text { America }\end{array}$ & 14.4 & 6.9 & V \& VI: 44\%; IV: 30.1\%; I \& II: 15\% \\
\hline Oceania & 14.2 & 15.6 & III \& IV: $\sim 60 \%$; I \& II: 23; V \& VI: 12\% \\
\hline $\begin{array}{l}\text { South } \\
\text { America }\end{array}$ & 25 & 3.9 & NR: 55\%; III \& IV: 18\%; I \& II: 16\% \\
\hline
\end{tabular}

Source: column 2 from UNEP, 2014, p.9 and 12; column 3 from UNEP-WCMC, 2014

\section{Key debates around protected areas}

The philosophy underpinning the first four protected area categories in Box 2, and how various countries operationalise their objectives in legislation and management practices, is not uncontroversial. For example, in New Zealand the National Parks Act 1980 requires that these protected areas should be 'preserved as far as possible in their natural state' and that 'the native plants and animals of the parks shall be as far as possible preserved and the introduced plants and animals shall as far as possible be exterminated'; further, it requires that 'their value as soil, water, and forest conservation areas should be maintained' (section 4.2). These are the only underpinning environmental values; a holistic, multilevel environmental perspective is missing, particularly concerns regarding air, soil and water impacts above local level, the exhaustion of non-renewable resources, and contributions to climate change of protected area-based activities.

Two important assumptions transpire from the objectives pursued for categories I-IV and from the New Zealand national park example. First, 'nature = non-human nature' (Hammer, 2007, pp.21, 26): for example, a specific objective of category IV is 'To provide a means by which the urban residents may obtain regular contact with nature' (Dudley, 2008, p.19). Second, the assumption is that good conservation is selective conservation, eliminating what lawmakers or dominant stakeholders view as non-native and not deserving to live. For example, trout and salmon are not native to New Zealand, but protected and tolerated for economic and recreational reasons; there are no policies around domestic cats threatening bird life, but possums are targeted with aerial poisoning.

In a book focusing on New Zealand's conservation approach, Benfield argues that managing nature areas is:

a quest to recreate a perfect word with everything in its place and all non-native species excluded. It also seeks a 'freeze frame moment', a moment frozen in time under a bell jar, the moment when in theory, evolution reached a point of perfection in balance and harmony - and then it stopped. In many New World cases like the US or New Zealand, the restoration model is often the time of first European contact. As nature is dynamic, as the world is in constant flux, to freeze evolution is an unachievable goal. We must seek to understand how regulatory authorities now try to

Table 2: Historic, current and future population

\begin{tabular}{lllllll}
\hline Year & Africa & Americas & Asia & Europe & Oceania & World \\
\hline 1950 & $228,826,701$ & $339,484,233$ & $1,395,749,366$ & $549,043,373$ & $12,674,996$ & $2,525,778,669$ \\
2000 & $808,304,337$ & $841,695,330$ & $3,717,371,723$ & $729,105,436$ & $31,223,602$ & $6,127,700,428$ \\
2100 & $4,184,577,429$ & $1,249,292,969$ & $4,711,514,029$ & $638,815,665$ & $69,648,478$ & $10,853,848,570$ \\
\hline
\end{tabular}

Source: UN-DESAPD, 2013 
lock native species into their 'range'. An example would be the Monterey Cypress. Endangered in its natural range, it is put down as an 'alien' only a few miles away from it as being 'out of range'. (Benfield, 2015, p.10)

Mose and Weixlbaumer (2007, pp.10-11) refer to this approach as the 'protection and segregation' or 'static preservationist' paradigm. Others use terms like 'land sparing' (Ellis, 2013) or 'fortress conservation' (Rodary and Milian, 2011). This paradigm dominated the world until the mid-20th century, and is still
An increasing number of academics and stakeholders consider that a better integration is needed of regulations on conservation and human development, which should include viable funding mechanisms for protected areas. Mose and Weixlbaumer identify this as the second paradigm, referring to it as the 'dynamicinnovation approach (integration protection)' or 'preservation and use integrated approach'. This builds on the principles of sustainable development and 'attempts to overcome the "protection and pollution area" dichotomy' (Mose and Weixlbaumer, 2007, pp.12-13). Other terms used are 'land sharing' (Ellis,

\section{Currently, some activities permitted by governments inside protected areas contribute to biodiversity decline and environmental quality deterioration, within and outside protected areas.}

preferred in some regions and by large and powerful international nature organisations (Aubertin, Pinton and Rodary, 2011). Increasingly, however, the usefulness of this paradigm has been challenged. Already in 1986 Tighem deplored that national parks persistently failed to deliver the expected biodiversity conservation objectives. $\mathrm{He}$ argued that:

[National parks] have not drawn us into a more thoughtful relationship with our habitat. They have not taught us that land is to be used frugally, and with good sense. They have encouraged us to believe that conservation is merely a system of trading environmental write-offs against large protected areas. They have more than failed, in fact, they have become a symptom of the problem. (Tighem, 1986)

As shown in Table 1, categories I and II now have the lowest shares of all protected area types, except in Oceania.
2013) and 'sustainable land use' (Rodary and Milian, 2011). Categories V and VI were added by the IUCN in 1992 (and classified retroactively: Dudley, 2008) to reflect criticism regarding the narrow focus on local nature. They are generally viewed as forming the backbone of this second paradigm, next to areas with 'not reported' management status. Rodary and Milliam (2011) found that more than half of 'not reported' areas are indigenous or forest reserves.

This article argues that the dichotomy approach to protected area governance conceptualisation is misleading and sets us on unproductive analytical tracks. A softer interpretation of protected area differences uses a spectrum approach, claiming that the degree of areas' naturalness decreases from category I to category VI (Dudley, 2008). The corollary is that their compatibility with human uses, and the de facto impacts, would increase from I to VI. Leroux and colleagues tested the common assumption that 'The gradient, from most natural to least natural, follows categories $\mathrm{Ia}=\mathrm{Ib}>\mathrm{II}=\mathrm{III}$
$>$ IV $=\mathrm{VI}>\mathrm{V}$ ', whereby natural 'is defined relative to both ecosystem structure and human activity'. Using the 'human footprint' technique, they found that 'the present assignment of protected areas to IUCN categories does not correspond to the expected gradient of naturalness in a globally consistent manner'. Interestingly, they also concluded that 'the grand mean Human Footprint of IUCN Category Ia areas is higher than for Category Ib, and is roughly equivalent to Categories II, III, and VI' (Leroux et al., 2010, p.610).

Consequently, it would be misleading to rely on general assumptions about compatibility with human uses to get a sense of the degree of (local) nature protection across protected area types. The way human access is regulated and implemented in various types of protected area is important. As always, 'the devil is in the detail'. ${ }^{3}$ In some countries category II sites may be more exposed to (risks of) environmentally unfriendly developments compared to category $\mathrm{V}$ or VI areas in other countries. The findings of Leroux and colleagues seem to suggest that this has happened, despite the 'freeze frame moment' approach to biodiversity management still embedded in some national legislations regarding category I-IV areas.

Development threats at the dawn of the third millennium

Currently, some activities permitted by governments inside protected areas contribute to biodiversity decline and environmental quality deterioration, within and outside protected areas. This is the case when they consume significant amounts of fossil fuels, and when activities such as fracking or the mining of minerals are allowed. An intensified use of motorised vehicles and the construction of numerous facilities with fossil fuel emissions within protected area boundaries will increase the deposition of nitrogen on flora, water bodies and soils; it will also lead to acidification through ground-level ozone and particular matter pollution. These factors may also affect fauna.

In New Zealand some national parks, or areas of national parks, are open to intensive tourism-related vehicle use (cars, buses, helicopters, motor boats). 
Since 2009 New Zealand governments have attempted to open up national parks for gold and coal mining. Recent attempts at coal extraction in national parks have been reported mostly in developing countries, but attempts at fracking under protected areas in developed countries are not uncommon (see Greenpeace, 2015). The following is a list of development threats to national parks (from Watson et al., 2014, p.70) posing environmental risks, from local to global:

- Indonesia: permits were issued for mining inside 481,000 hectares of national parks and protected areas in 2010.

- Belize: permit approved in 2012 for petroleum exploration inside Sarstoon Temash National Park, the second largest national park in Belize and a Ramsar-listed site.

- Democratic Republic of Congo: intention to explore for petroleum inside Virunga National Park was affirmed in 2012.

- Japan: restrictions on drilling were eased to allow diagonal drilling inside national parks in 2012.

- United Kingdom: Cairngorms National Park management plan, announced in 2010, expands development inside the park, including plans for the construction of 1,700 houses.

- Australia: recent changes in protected area management allowed grazing, recreational shooting, fishing and other uses.

In New Zealand, coal mining in the conservation estate is still possible. In 2014 the conservation minister approved a concession for an open-cast coal mine covering over 106 hectares on the Denniston Plateau, near Westport. He stated: 'I have approved this mine because the loss of conservation values is compensated by a $\$ 22$ million package by Bathurst Resources. The compensation will fund pest and predator control' (Smith, 2013). Bearing in mind that the Department of Conservation's restructuring resulted in 312.7 permanent full-time equivalent staff being dedicated to 'partnerships with businesses and communities' (Department of Conservation, 2015), the question arises: are donations the new currency for concession allocation in New Zealand's protected areas? Irrespective of where this coal will be used, it will contribute to climate change, which is expected to have a significant negative impact on native biodiversity (McGlone and Walker, 2011). Is the developer's donation going to do more good to biodiversity than climate change will eventually do damage, in the medium and long term? New Zealand may indeed be an island, but localglobal environmental linkages cannot be denied. In early 2016 public consultation was opened on another concession, for Rangitira Developments Limited. The term 'compatible with' - in the definitions of protected areas' objectives and the larger legal-policy frameworks - by using the concept of strong sustainability. Rather than looking narrowly at potential direct negative impacts on species, local ecosystems and habitats, natural monuments, or only some environmental resources, authorities need to screen all human access and infrastructure proposals in terms of compatibility with strong sustainability objectives and principles, and the relevant recent scientific insights; when science is uncertain, the precautionary principle needs to be applied to decision-making.

\section{The Planetary Boundary framework offers a reminder that proper care for protected areas needs to consider the multi-scale interactions between humans and planetary biogeochemical systems.}

intended activity is again open-cast coal mining, on 12 hectares on Mt Te Kuha near Westport.

Of relevance here are also pollution incidents. These can be expected to increase with the intensified commercialisation of protected areas based on narrowly considered environmental risks. In 2013 the concessionaire Ruapehu Alpine Lifts was responsible for spilling thousands of litres of diesel into the water supply of neighbouring communities. It was claimed that 'about 19,000 litres was pumped into the Tongariro National Park, a World Heritage Area', and the company was subsequently convicted and fined $\$ 300,000$. Local residents have recently laid a complaint to police, as 15,000 litres of diesel cannot be apparently accounted for (next to the 3000-4000 litres believed to have spilled during the incident on 26 September 2013), and they struggle with the question whether the water supply was affected by pollution before the incident (see Brooker and Wall, 2015).

This article argues in favour of widening the operationalisation of the
Strong sustainability approaches to human uses can be applied across all protected area categories without undermining their distinctiveness, because human access is allowed in various forms anyway. Concessions (permits, licenses, leases) are regulatory tools typically applied to enable access to protected areas. They can be used as tools for the implementation of sustainability objectives. The new types of concession conditions will need to be reflected in the higher-level nature management plans and strategies. They also need to be harmonised with national environmental policies and legislation, which in their turn may need revision.

For example, at concession level, users are typically required to refrain from actions resulting in environmental damage (see Dinica, forthcoming, 2017). In New Zealand, the Conservation Act 1980 uses the terms 'avoid, remedy or mitigate'. But, by applying a strong sustainability approach, concessionaires and other users could also be required to proactively engage in activities that reverse already 
Figure 1: Planetary boundaries and interlinkages with biodiversity and protected areas

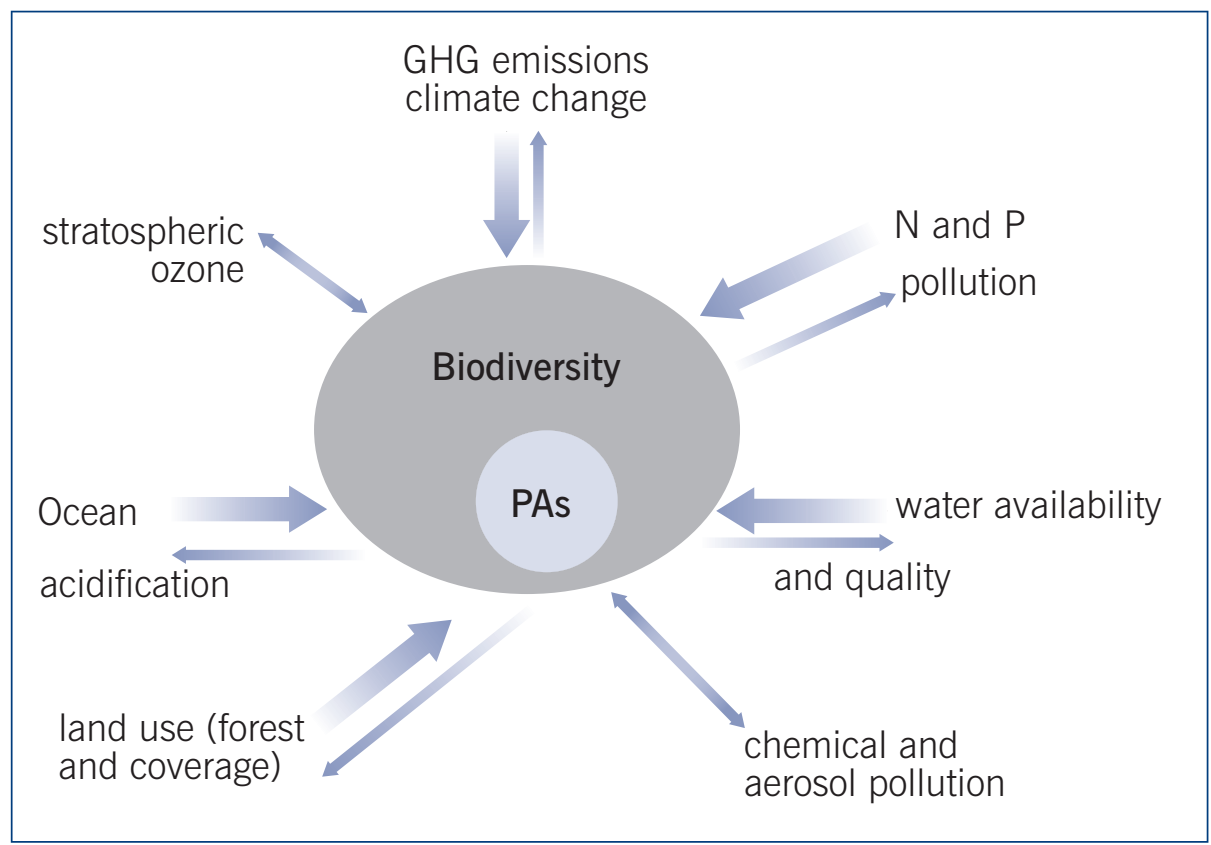

Source: based on Mace et al., 2014; using the authors' approach, bold arrows suggest stronger impacts

sustained damage (ecological restoration, for example) or aid transitions, such as towards renewable energy use (see Green and Winebrake, 2006), sustainable transport, organic multi-crop agriculture or sustainable waste management, within or outside protected areas. In this way, all protected areas could become 'exemplary landscapes', spaces of human-nature interaction that people and businesses would like to emulate elsewhere, and which societies may be more willing to support financially (Ervin, 2013).

\section{Strong sustainability and planetary \\ boundaries}

The strong sustainability concept maintains that 'the stable functioning of Earth systems - including the atmosphere, oceans, forests, waterways, biodiversityand biogeochemical cycles - is a prerequisite for a thriving global society' (Griggs et al., 2013, p.305). This means that in the process of human development, societies should not alter the ecosphere - which includes fauna, flora, the atmosphere, and water and soil quality and availability - to an extent that poses risks to human and non-human life or disrupts evolutionary processes irreversibly. In contrast to weak sustainability, the strong sustainability approach does not accept that natural and human-made capital can be seen as interchangeable. Rather, the economy is seen as an element of society, which in turn is seen as an element in the global eco-geosphere. The strong sustainability approach considers that human development needs to focus on poverty reduction, and on human wellbeing and health, rather than economic growth (Neumayer, 2013).

In 2009, 28 internationally acknowledged scientists, working in collaboration with the Stockholm Resilience Centre, published the Planetary Boundary framework, underpinned by the strong sustainability concept and inspired by the famous book The Limits to Growth (Donella Meadows et al; 1972). The underlying idea is that nine interlinked boundaries need to be observed to maintain 'a safe operating space for humanity'. These refer to: biodiversity; climate change; the nitrogen cycle (tightly linked to the phosphorus cycle); change in land use; stratospheric ozone depletion; ocean acidification; global freshwater use; atmospheric aerosol loading; and chemical pollution (Rockstrom et al., 2009a, 2009b). In their revised version, the authors argue that the first five listed boundaries have already been broken. For the climate and land-system change, the planet is still in the zone of 'increasing risk', while for the other three, the high-risk zone, which is 'beyond the zone of uncertainty', has already been reached. The biodiversity and nitrogen boundaries have been 'overstepped' the most, quantitatively.
The climate boundary needs to be watched very closely. Climate changes are expected to generate many other rapidly occurring planetary changes, threatening all life forms. In the hierarchy of boundaries, biodiversity and climate are the ones that radically influence all transitions across geological eras, and need to be urgently addressed by decision-makers. But they are influenced by all others. The strongest interlinkages are between the following boundaries: biodiversity, climate change, land-system change, water, nitrogen and phosphorus, and ocean acidification. The strongest impacts on biodiversity are from these (Mace et al., 2014, pp.294-5). Figure 1 represents these relationships and their relevance for protected areas. These interactions are highly complex and occur at all levels, from local to global.

As hotspots of biodiversity, protected areas are exposed to many pollution forms from neighbouring areas, as well as regional and global anthropogenic environmental changes. Mora and Sale explain how biodiversity is significantly influenced by residential areas, agriculture and food industries, and energy production systems (Mora and Sale, 2011, pp.257-9; Mace et al., 2014; Rockstrom et al., 2009a). These influences occur through over-exploitation, invasive species, sewage pollution, leakages from landfills, erosion, climate change, and eutrophication and acidification through various air pollutants such as sulphur dioxide, nitrogen oxides, ozone, particulate matter and ammonia. However, as argued earlier, what happens within protected areas will also reverberate outside these spaces, at regional and global levels. The Planetary Boundary framework offers a reminder that proper care for protected areas needs to consider the multiscale interactions between humans and planetary biogeochemical systems.

Jamison Ervin (an advisor with the United Nations Development Programme) argues also in favour of integrating sustainability into protected area governance, writing that 'we must fundamentally change how we think about protected areas. We must repurpose protected areas to obtain not only ecological but also sustainable 
development goals' (Ervin, 2013, pp.76-7). Such a fundamental rethinking of protected areas can only start with the widening of the objectives underpinning the governance and management plans of all protected area types, to reflect the state of the global environment. Social, economic and cultural values are already represented in protected areas' conceptualisation, but they need to be refined and qualified in the light of the more comprehensive range of environmental sustainability values.

This requires balancing perspectives from the outside in (focusing on the negative impacts on and the positive impacts emanating from protected areas) with inside-out perspectives (how can protected area governance be improved to avoid negative impacts at regional and global level, and engage more proactively in multi-scale environmental improvements). While so far the focus of protected area governance and of traditional conservationists has been on the bolded arrows in Figure 1, the thinner, outwards-pointing arrows
Figure 2: Proposed sustainable development goals to integrate planetary boundaries ideas with Millennium Development Goals (revised in 2015)

\begin{tabular}{|c|c|c|}
\hline \multicolumn{3}{|c|}{ New Definition of Sustainable Development } \\
\hline $\begin{array}{l}\text { Updated Millennium } \\
\text { Development Goals }\end{array}$ & $\begin{array}{l}\text { Planetary } \\
\text { Must-Haves }\end{array}$ & $\begin{array}{l}\text { Sustainable } \\
\text { Development }\end{array}$ \\
\hline $\begin{array}{l}\text { End poverty and hunger } \\
\text { Universal education } \\
\text { Gender equality } \\
\text { Health } \\
\text { Environmental } \\
\quad \text { sustainability } \\
\text { Global partnerships }\end{array}$ & $\begin{array}{l}\text { Materials use } \\
\text { Clean air } \\
\text { Nutrient ( } N \text { and P cycles) } \\
\text { Hydrological cycles } \\
\text { Ecosystem services } \\
\text { Climate stability } \\
\text { Biodiversity }\end{array}$ & $\begin{array}{l}\text { Thriving lives and livelihoods } \\
\text { Sustainable food security } \\
\text { Sustainable water security } \\
\text { Universal clean energy } \\
\text { Healthy and productive } \\
\text { ecosystems } \\
\text { Governance for sustainable }\end{array}$ \\
\hline 2000 & 2015 & 2030 \\
\hline
\end{tabular}

Source: Griggs et al., 2013

cannot be ignored any longer. Box 1 - the IUCN's delineation of use and non-use values - mentions climate stabilisation as a benefit of protected areas (often in the hope of attracting financial support for ecosystem services). However, how much of a benefit is there if activities permitted within protected areas extract and/or consume (often intensively) fossil fuels (contributing also to acidification)? Likewise, the extraction of non-renewable resources and the logging of native forests detract from the 'future uses' value of protected areas.

The revised Planetary Boundary framework proposes to monitor the

Table 3: Expanding the objectives for protected area governance (the range and hierarchy of socio-economic objectives may vary across protected area types)

What is to be sustained through protected area governance (objectives)?

The environment (holistic view)

- biodiversity (managed and monitored for phylogenetic species variability: see Mace et al., 2014; Steffen et al., 2015)

- air quality

- water and soil quality and availability (for services to the ecosphere, including human society)

- climate stability

- ocean biochemical stability

- non-renewable mineral and organic resources (e.g. no extraction of nonrenewables within protected areas; use rates or organic resources that consider sustainability impacts at all levels; resource efficiency; sustainable architecture)

- the diffusion of renewable resources; energy efficient technologies/ behaviours

Socio-cultural aspects

- (local/national) cultural and historical artefacts and traditions

- social equity, inter- and intragenerational facilities/activities

- environmental justice

- human spiritual development and health

- education and research
Well-being and green commercial innovations
- opportunities for environmentally friendly and equal opportunity employment

- businesses facilitating environmentally friendly innovations and user adoption

- an adequate material standard of living (locally to nationally), through ethical investments by national businesses or individuals (to reduce financial leakages from the national economy) 
land-system change boundary based on forested area, suggesting a maximum 50\% loss from the potential/initial forest cover globally for temperate forests, and no less than 15\% loss of original forest cover for tropical and boreal forests (Steffen et al., 2015, pp.1259855-7). While governments may view the logging of native forests as environmentally sustainable locally, it may undermine global environmental sustainability. There can be no such thing as local sustainable development without development that is globally environmentally sustainable.

Griggs and colleagues argue that the Planetary Boundary framework offers the opportunity to redefine a set of sustainable development goals, as reproduced in Figure 2. They believe that decisionmakers at all levels should reconsider the Brundtland definition of sustainability ${ }^{4}$ by incorporating scientific findings that have emerged during the decades since 1987. They consider that a new definition of sustainable development is necessary in the Anthropocene: 'Development that meets the needs of the present while safeguarding Earth's life-support system, on which the welfare of current and future generations depends' (Griggs et al., 2013, p.306).

\section{A preliminary research agenda}

Considering the age of the protected area concept, this article set out to examine what such spaces should aspire to achieve in the third millennium, given contemporary pressures and challenges.
Arguments were offered in favour of incorporating a strong sustainability approach into protected area governance. Table 3 suggests, in column 1, an extended range of environmental objectives. The social and economic objectives suggested draw on existing practice, particularly the IUCN/Convention on Biological Diversity approach, but have been refined to be coherent with the more comprehensive, multi-scale environmental objectives. The list represents just a preliminary proposal for further thinking and research.

This approach necessitates a new research agenda, which should address questions such as:

- What sustainability-driven objectives are most suitable for which

protected area categories, and in what hierarchy? What indicators and criteria should be selected to reflect progress in their achievement at protected area level?

- What governance innovations would be required to implement the new set of sustainability-driven objectives for various protected area categories? What legislative changes, institutional designs and interactions, new governance principles, processes, instruments and actor arrangements are likely to be effective? What cultural, societal, geographical, economic and other preconditions may influence their effectiveness? Some immediate, more specific research questions would be:
- How should environmental impact assessments, strategic environmental assessments and other comparable policy instruments be revised to help implement the new objectives?

- What are the implications of a sustainability-driven approach to protected areas for the collaboration of public authorities, and policy integration across governmental scales and policy domains? How can the private sector contribute to the implementation of the new approach?

The answers to such questions are crucial, as they will influence the extent to which the potential of protected areas to contribute to global sustainability is harnessed.

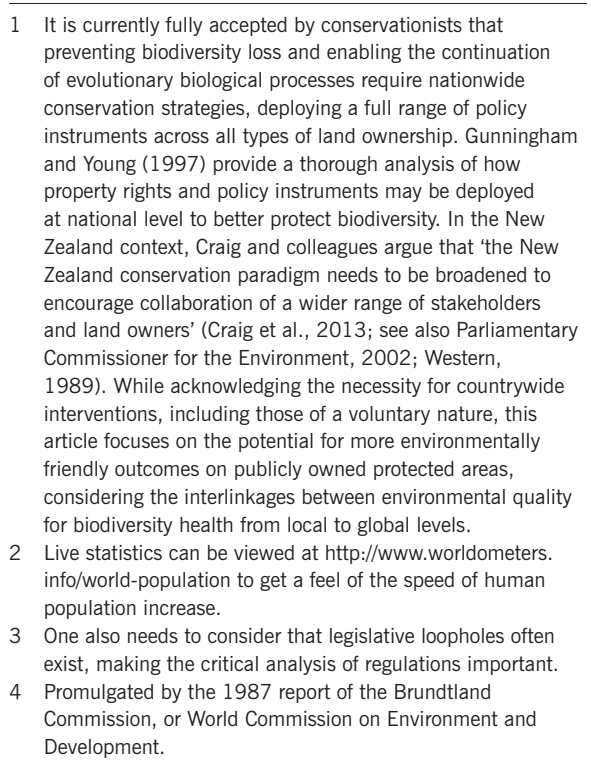

\section{References}

Adams, W.M and M. Muligan (eds) (2003) Decolonizing Nature: strategies for conservation in a post-colonial era, London: Earthscan Aubertin, C., F. Pinton and E. Rodary (2011) 'Sustainable development: a new age for conservation?, in E. Rodary and E. Aubertin (eds), Protected Areas: sustainable lands?, Farnham: Ashgate

Balmford, A., J.L. Moore, T. Brooks, N. Burgess, L.A. Hansen, P. Williams and C. Rahbek (2001) 'Conservation conflicts across Africa', Science, 291 (5513), pp.2616-9

Benfield, W.F. (2015) At War with Nature: corporate conservation and the industry of extinction, Wellington: Tross Publishing

Brooker, L. and T. Wall (2015) 'The Ruapehu skifield spill: a community's anger', http://www.stuff.co.nz/national/68729679/The-Ruapehuskifield-spill-a-communitys-anger

Carter, J.G., C.M. Wood and M. Baker (2003) 'The environmental appraisal of national park management plans in England and Wales', Journal of Environmental Planning and Management, 46 (2), pp.27188
Craig, J., H. Moller, D. Norton, D. Saunders and M. Williams (2013) ‘Enhancing our heritage: conservation for 21st century New Zealanders: ways forward from the Tahi group of concerned scientists', Pacific Conservation Biology, 19, pp.256-69

Department of Conservation and Tongariro Natural History Society (1998) The Restless Land: stories of Tongariro National Park world heritage area, Turangi: Everbest Printing

Department of Conservation (2015) 'Four-Year Plan: budget 2015', Wellington, retrieved from http://www.doc.govt.nz/Documents/aboutdoc/four-year-plan/doc-four-year-plan-2015.pdf

Dinica, V. (forthcoming, 2016) 'Tourism concessions in national parks: neo-liberal governance experiments with a conservation economy in New Zealand', Journal of Sustainable Tourism, special issue on 'Financing protected area and tourism', available from 20 February 2016 at http://dx.doi.org/10.1080/09669582.2015.1115512

Dixon, J.A. and P.B. Sherman (1990) Economics of Protected Areas: new look at benefits and costs, London: Earthscan 
Dudley, N. (ed.) (2008) Guidelines for Applying Protected Area Management Categories, Gland: IUCN, https://portals.iucn.org/library/ efiles/documents/PAPS-016.pdf

Ehrlich, P.R. and R.M. Pringle (2008) 'Where does biodiversity go from here? A grim business-as-usual forecast and a hopeful portfolio of partial solutions', Proceedings of the National Academy of Sciencs, 105 (1), pp.11579-86

Ellis, E.C. (2013) 'Sustaining biodiversity and people in the world's anthropogenic biomes', Current Opinion in Environmental Sustainability, 5 (3-4), pp.368-72

Ervin, J. (2013) 'The three new R's for protected areas: repurpose, reposition and reinvest', Parks, 19 (2), pp.75-84

Green, E.H. and J.J. Winebrake (2006) 'An assessment of renewable energy potential for US national parks', Strategic Planning for Energy and the Environment, 25 (4), pp.39-55

Greenpeace (2015) 'Energy files: fracking company expressed concern over national park drilling ban months before it was repealed', retrieved 10 January 2016 from http://energydesk.greenpeace. org/2015/10/27/energy-files-fracking-company-expressed-concernover-national-park-drilling-ban-months-before-it-was-repealed/

Griggs, D., M. Stafford-Smith, O. Gaffney, J. Rockström, M.C. Öhman, P. Shyamsundar, W. Steffen, G. Glaser, N. Kanie and I. Noble (2013) 'Policy: sustainable development goals for people and planet', Nature, 495, pp.305-7

Gunningham , N. and M.D. Young (1997) 'Toward optimal environmental policy: the case of biodiversity conservation', Ecology Law Quarterly, 24 (2), pp.243-98

Hammer, T. (2007) 'Protected areas and regional development: conflicts and opportunities', in I. Mose (ed.), Protected Areas and Regional Development in Europe: towards a new model for the 21st century, Farnham: Ashgate

IUCN (1998) Economic Values of Protected Areas: guidelines for protected area managers, Gland: IUCN and Cardiff University, retrieved 12 December 2015 from https://portals.iucn.org/library/ efiles/documents/PAG-002.pdf

Leroux, S.J., M.A. Krawchuk, F. Schiemeglow, S.G. Cumming, K. Lisgo, L.G. Anderson and M. Petkova (2010) 'Global protected areas and IUCN designations: do the categories match the conditions?', Biological Conservation, 143 (3), pp.609-16

Mace, G.M. et al. (2014) 'Approaches to defining a planetary boundary for biodiversity', Global Environmental Change, 28, pp.289-97

McGlone, M. and S. Walker (2011) Potential Effects of Climate Change on New Zealand's Terrestrial Biodiversity and Policy Recommendations for Mitigation, Adaptation and Research, Science for Conservation report 312, Wellington: Department of Conservation

Meadows, D. H.; Meadows, D. L.; Randers, J.; Behrens III, W. W. (1972), The Limits to Growth: a report for the Club of Rome's project on the predicament of mankind, Universe Books, ISBN 0-87663$165-0$

Molloy, L. (2016) 'Protected areas: New Zealand's protected areas', in Te Ara - the Encyclopedia of New Zealand, http://www.teara.govt.nz/en/ protected-areas/page-1

Mora, C. and P.F. Sale (2011) 'Ongoing global biodiversity loss and the need to move beyond protected areas on land and sea', Marine Ecology Progress Series, 434, pp.251-66

Mose, I. and N. Weixlbaumer (2007) 'A new paradigm for protected areas in Europe', in I. Mose (ed.), Protected Areas and Regional Development in Europe: towards a new model for the 21st century, Farnham: Ashgate
National Parks Services (2012) 'Commitment to sustainability', retrieved 11 January 2016 from http://www.nps.gov/yell/parkmgmt/ sustainability-commitment.htm

Neumayer, E. (2003) Weak Versus Strong Sustainability: exploring the limits of two opposing paradigms, Northampton: Edward Elgar

Noss, R.F., A.P. Dobson, R. Baldwin, P. Beier, C.R. Davis, D.A. Dellasala, J. Francis, H. Locke, K. Nowak, R. Lopez, C. Reining, S.C. Trombulak and G. Tabor. (2012) 'Bolder thinking for conservation', Conservation Biology, 26 (1), pp.1-4

Parliamentary Commissioner for the Environment (2002) Weaving Resilience into our Working Lands: recommendations for the future roles of native plants on private land, Wellington: Parliamentary Commissioner for the Environment

Rockstrom, J. et al. (2009a) 'Planetary boundaries: exploring the safe operating space for humanity', Ecology and Society, 14 (2), http:// www.ecologyandsociety.org/vol14/iss2/art32/

Rockstrom, J. et al. (2009b) 'A safe operating space for humanity', Nature, 461 (7263), pp.472-5

Rodary, E. and J. Milian (2011) 'Expansion and diversification of protected areas: rupture or continuity?', in E. Rodary and E. Aubertin (eds), Protected Areas: sustainable lands?, Farnham: Ashgate

Smith, N. (2013) 'Denniston coal mine gains access aproval', media release, 23 May, Office of the Minister of Conservation, http://www. doc.govt.nz/news/media-releases/2013/denniston-coal-mine-gainsaccess-approval/

Steffen, W. et al. (2015) 'Planetary boundaries: guiding human development on a changing planet', Science, 347 (6223)

Thompson, I.B. (2008) 'Sustainable rural development in the context of a high mountain national park: the Parc National de la Vanoise, France', Scottish Geographical Journal, 115 (4), pp.297-318

Tighem, K.V. (1986) 'Have our national parks failed us?', Park News, 22 (2), pp.31-3 http://wdpa.s3.amazonaws.com/WPC2014/protected_ planet_report.pdf

UN-DESAPD (2013) 'World population prospects', United Nations Department of Economic and Social Affairs, Population Division, retrieved 6 January 2016 from http://www.geohive.com/earth/his proj_continent.aspx

UNEP-WCMC (2014) Global Statistics from the World Database on Protected Areas, Cambridge: United Nations Environmental Programme, World Conservation Monitoring Centre

United Nations Environmental Programme (2008) 'Summary of protection by country and territory on the 31st January 2008', World Database on Protected Areas, available at http://www.protectedplanet.net

United Nations Environmental Programme (2014) Protected Planet Report 2014, retrieved 7 January 2016 from

Watson, J.E.M., N. Dudley, D.B. Segan and M. Hockings (2014) 'The performance and potential of protected areas', Nature, 515, pp.6773

Western, D. (1989) 'Conservation without parks: wildlife in the rural landscape', in D. Western and M.C. Pearl (eds), Conservation for the Twenty-first Century, New York: Oxford University Press

Wiersma, Y.F. and T.D. Nudds (2006) 'Conservation targets for viable species assemblages: data independent targets are not appropriate', Biodiversity and Conservation, 15, pp.4555-67

Woodley, S. et al. (2012) 'Meeting the Aichi Target 11', Parks, 18 (1), pp.23-36 